\title{
POLIGAMI DALAM METODE TAFSIR AL-QUR'AN MUHAMMAD SHAHROUR
}

\author{
Evi Muzaiyidah Bukhori \\ Institut Agama Islam Negeri (IAIN) Jember \\ evimuzaiyidab@gmail.com
}

\begin{abstract}
Abstrak
Tulisan ini dilatarbelakangi oleh keinginan kuat untuk mempublikasikan masterpiece seorang mufasir kontroversial dari Suriah yang menawarkan pembacaan baru terhadap Al-Qur'an bernama Muhammad Shahrour. Dalam tafsirnya terhadap Al-Qur'an, Shahrour telah mengundang berbagai polemik dan respon-respon yang tidak jarang bernada negatif. Shahrour bukanlah satu-satunya mufasir modern-kontemporer anti maenstreem, terdapat juga mufasir lain seperti Muhammad Arkoun. Namun menarik untuk dicatat adalah metodologi tafsir AlQur'an Shahrour gunakan untuk membaca isu-isu perempuan yang masih terus-menerus diperdebatan sampai hari ini yaitu isu poligami. Hasil tulisan ini adalah Pembacaan Shahrour terhadap Al-Qur'an sedikit banyak dipengaruhi oleh setting sosial di mana ia hidup. Terutama pergumulannya dengan dengan teman sekaligus guru bernama 'Ja'far Dakk al-Bab. Semenjak itu Shahrour mulai mendalami Al-Qur'an. Muhammad Shahrour memandang salah satu problem terbesar dalam penafsiran Al-Qur'an adalah problem aplikasi metodologi penafsiran. Konsep kunci pemikiaran Shahrour adalah teori tentang Hudud. Teori ini terutama dipakai untuk membaca persoalan-persoalan hukum yang terdapat dalam ajaran Islam khususnya isu poligami memiliki pemahaman yang unik dibandingkan dengan ulama-ulama terdahulu.
\end{abstract}

Kata Kunci : Metode Tafsir, Hudud, Poligami

\begin{abstract}
This paper is motivated by a strong desire to publish a masterpiece of a controversial commentator from Syria who offers a new reading of the Qur'an named Mubammad Shabrour. In his commentary on the Qur'an, Shahrour has invited various polemics and responses that are often negative in tone. Shabrour is not the only modern-contemporary anti-maenstreem commentator, there are also other commentators such as Mubam-mad Arkoun. However, it is interesting to note that the methodology of Al-Qur'an Shabrour exegesis uses to read women's issues which are still being debated to this day, namely the issue of polygamy. The result of this paper is that Shabrour recitation of the Al-Qur'an is more or less influenced by the social setting in which be lives. Especially his struggles with a friend and teacher named Ja'far Dakek al-Bab. Since then Shahrour began to study the Qur'an. Mubammad Shabrour sees that one of the biggest problems in the interpretation of the Qur'an is the problem of the application of the methodology of interpretation. The key concept of Shabrour 's thinking is the theory of Hudud. This theory is mainly used to read legal issues contained in Islamic teachings, especially the issue of polygamy, which has a unique understanding compared to previous scholars.
\end{abstract}

Keywords: Methods of Tafseer, Hudud, Polygamy

Pusat Studi Gender dan Anak (PSGA) LP2M IAIN Jember | 43 


\section{Evi Muzaiyidah Bukhori}

\section{Pendahuluan}

Al-Qur'an adalah kitab suci umat Islam yang didalamnya berisi ajaran hubungan manusia dengan Allah, sesama manusia dan alam semesta yang abadi sepanjang masa. Sebagai pedoman hidup, AlQur'an diyakini akan terus terjaga kemurnian ajarannya sampai akhir zaman. Allah Swt berfirman :

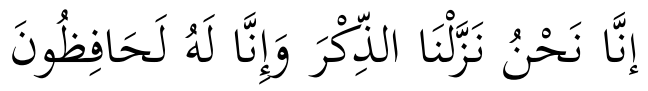

Artinya : Sesunggubnya Kami-lah yang menurunkan Al Quran, dan sesunggubnya Kami benar-benar memelibaranya. (QS:Al-Hijr: 9)

Namun kenyataannya, Al-Qur'an sering 'dipahami' secara bahan bacaan tekstual saja sehingga menyebabkannya kemalasan untuk mendalami kandungan ayat A-Qur'an. Fenomena inilah yang menggelisahkan para mufasir modernkontemporer, seperti Fazlur Rahman, Muhammad Arkoun, Hassan Hanafi, Nasr Hamid Abu Zaid, dan Muhammad Shahrour.

Menurut para mufasir kontemporer tersebut, yang dibutuhkan saat ini adalah pemahaman Al-Qur'an mengaplikasikan model \& metodologi baru. Hal yang demkian bertujuan 'agar kitab suci umat Islam ini menjadi "pedoman hidup dan jawaban atas masalah' yang terjadi pada setiap aspek kehidupan manusia,baik ekonomi, pendidikan, politik maupunl sosial. Artinya perlu adanya perubahan atau pergeseran paradigma pemahaman Al-Qur'an dari paradigma literalis-ideologis yang sudah berlangsung selama beberapa abad lamanya menjadi paradigma kritis-kontekstual. Tanpa adanya perubahan paradigma dalam membaca dan memahami kalam Tuhan tersebut maka yang muncul hanyalah pembacaan berulang-ulang dan tidak produktif.

Adalah Muhammad Shahrour seorang pemikir kontroversial dari Suriah yang menawarkan pembacaan baru terhadap alQuran dalam karyanya al-Kitäb wa al-Qur'ān: Qirāah Mu'asirah. Terbit pada tahun 1990, buku Shahrour ini menimbulkan polemik di dunia Arab, baik antara pendukung maupun penentangnya. Pemikirannya memunculkan berbagai buku yang ditulis untuk memberikan apresiasi baik kritik maupun persetujuan seperti yang dilakukan oleh Sulaiman al-Jabi, Jamal al-Banna, Ahmad 'Imran, Jawad 'Afanah, M. Sa'id Ramadan alButi dan Nasr Hamid Abu Zaid.

Shahrour menggunakan pendekatan linguistik modern berbasis metode yang disebutnya sebagai al-tartil. Metode al-tartil adalah upaya mengaitkan jaringan antar satuan ayat yang memiliki kesamaan topik dalam al-Qur'an atau dikenal dalam pembahasan tafsir secara umum sebagai metode tematik (maudu'i). Kajian Shahrour menempatkan hubungan al-Qur'an sebagai hubungan intrateks yaitu hubungan antar bagian teks. Sebagai basis metodologis 
utama Shahrour dalam pembacaan barunya terhadap al-Qur'an, tulisan ini akan mendeskripsikan metode intratekstualitas alQur'an dalam pandangan Shahrour dan menemukan karakteristiknya dengan melakukan komparasi dengan pemikir lain. Selain itu, dalam tulisan ini akan dijelaskan ijtihad Shahrour dengan menggunakan pendekatan teori budund dalam menganalisis kasus-kasus terkait perempuan yang berkembang di masyarakat terutama isu poligami.

\section{Pembahasan}

\section{Biografi Muhammad Shahrour}

Muhammad Shahrour Dayb merupakan salah satu pemikir muslim liberal lahir di Salihiyyah, salah satu distrik di kota Damaskus Syria pada 11 Maret 1938. Shahrour terlahir dari pasangan Dayb ibn Dayb (1902 - 2002) dan Siddiqah binti Shalih Falyun dari sebuah keluarga menengah. Hingga saat ini, Muhammad Shahrour masih hidup dan menetap di Damaskus (Suriah).

Dalam catatan sejarah, Syiriah atau Suriah merupakan negara yang memiliki dampak yang cukup besar dalam belantika pemikiran Islam, baik sosial, politik, budaya, maupun intelektual. Negeri ini banyak melahirkan banyak pemikir muslim seperti Musthafa as-Siba’i dan Muhammad Sa’id
Hawwa. Mereka adalah pengawas umum yang aktif dalam gerakan Al-Ikhwan AlMuslimun. ${ }^{1}$ Di era kontemporer, muncul para tokoh pemikir Syiria yang dikategorikan sebagai tokoh gerakan sekularisme baru di dunia Arab seperti Azis al-Azmeh'.

Pemerintah Syiria memberikan perhatian besar terhadap dunia pendidikan. Salah satu buktinya adalah melimpahnya pemberian biaya pendidikan gratis atau 'beasiswa' terhadap siswa maupun mahasiswa yang menuntut ilmu disana. Dengan hal ini, sangatlah wajar jika sebagian besar masyarakat bebas buta huruf hingga $75 \%$ dari total jumlah penduduk Syiria. Terdapat empat universitas yang di Syiria, antara lain Universitas Aleppo, Universitas Teshreen, Universitas Damaskus dan Universitas al-Ba'ath. Iklim akademik yang kondusif memberikan motivasi bagi karier akademik Shahrour di Suriah sehingga ia berhasil menempuh' pendidikan ke Moskow Uni Soviet. ${ }^{2}$

Figur Shahrour sebagai pemikir liberal Islam Arab' di era -kontemporer cukup mengejutkan. Hal ini karena setelah ditelusuri latar belakang pendidikannya, ia tidak pernah belajar ilmu-ilmu keislaman

\footnotetext{
1 Philips Khoury, "Muslim Brotherhood in Syiria", dalam Burhanuddin, 'Hans Collection of Islamic Studies', (tidak diterbitkan ), 191-194.

2 Abdul Mustaqim, Epistemologi Tafsir Kontemporer, (Yogyakarta: LkiS, 2011), 93
} 


\section{Evi Muzaiyidah Bukhori}

secara intensif seperti Fazlur Rahman. Setelah menyelesaikan sekolah di tingkat dasar dan menengah di Lembaga Pendidikan "Abdurraman al-Kawakibi", selanjutnya hijrah ke 'Uni Soviet dengan memilih 'program diploma' bidang Teknik Sipil (Handasah Madaniyyah) dengan bekal beasiswa pemerintah setempat. Saat belajar di Moskow itulah Shahrour mulai mengenal dan mempelajari pemikiran Marxisme. Dia juga 'mengkaji filsafat dialektika Hegel dimana hal tersebut banyak mempengaruhinya- ketika menafsirkan 'AlQur'an, khususnya terkait "trilogi hermeneutikanya": "kaynunah (being), 'sayrurah (process), dan 'shayrurah (becaming).' Dengan demikin, muncullah 'mayorita ulama yang kontra atas ideology-pemiikiran Shahrour, seperi Munir asy- Syawwaf yang menuduhnya sebagai tokoh yang sangat terpengaru oleh pemikiran 'Marxisme' dan filsafat 'dialektika Hegel'.

Pada tahun 1964, Shahrour kembali ke Suriah dan bekerja sebagai dosen di Universitas Damaskus. Pada 1967, dia memperoleh kesempatan untuk melakukan penelitian di Imperial College di London Inggris. Namun, Shahrour harus kembali lagi ke Suriah karena terjadi perang antara Suriah dan Israil yang mengakibatkan hubungan diplomatik antara Suriah dengan Inggris menjadi ikut terputus. Peristiwa itu terjadi tepatnya pada Juni 1967.

$\begin{array}{lll}3 & \text { Abdul Mustaqim, Epistemologi Tafsir } \\ \text { Kontemporer, } 94 & \end{array}$

Akhirnya, pada 1968, Shahrour memutuskan untuk pergi ke Dublin Irlandia sebagai utusan dari Universitas Damaskus dalam rangka mengambil program Master dan Doktor di Ireland National University. Bidang keilmuan yang diambil adalah Mekanika Pertanahan dan Teknik Bangunan. Berkat ketekunannya, pada 1969 ia berhasil meraih gelar Master of Science, sedangkan gelar doktornya diraih pada $1972 .{ }^{4}$

Setelah menyelesaikan studinya di Ireland National University, Shahrour kembali ke Suriah dan resmi menjadi dosen di Universitas Damaskus dan mengampu mata kuliah Mekanik Pertanahan dan Geologi. Selain menjadi dosen, dia juga menjadi konsultan di bidang teknik. ${ }^{5}$ Di tahun 1982-1983, Shahrour diutus kembali oleh pihak Universitas Damaskus mejadi staf ahli di as-Sand Consult di Saudi Arabia. Berbarengan dengan -temannya, Shahrour membuka 'biro konsultasi Teknik bertempat di Damaskus.

Tahun 1995, Shahrour terlibat dalam acara debat publik mengenai pemikiran Islam di Libanon dan Maroko. ${ }^{6}$ Pada awalnya Shahrour lebih menekuni pendidikan teknik, namun seiring perkembangan, ia tertarik dengan kajian keislaman, terutama sejak berada di Dublin

4 M. Aunul Abied Shah 1. (ed.), Islam Garda Depan': Mosaik Pemikiran Islam Timur Tengah (Bandung: Mizan, 2001), 237

5 Charles Kurzman (ed.), Liberal Islam (New York: Oxford University Press, 1998), 139.

${ }^{6}$ M. Aunul Abied Shah et al. (ed.), Islam Garda Depan.., 237. 
Irlandia (1970-1980). Saat itulah Shahrour mulai mendalami dan mengkaji Al-Qur'an dengan menerapkan pendekatan teori linguistik, filsafat, dan sains modern. Tidak hanya itu, Shahrour berhasil melahirkan' berbagai buku \& artikel terkait 'pemikiran keislaman'.

Ja'far Dakk al- Bab, dia adalah 'rekan dan guru Shahrour yang mempunyai posisi luar biasa untuk' mendukung karir akdemik Shahrour. Keduanya bertemu ketika menjadi mahasiswa di Uni Soviet. Shahrour memilih' Jurusan Teknik Sipil dan Ja'far mengambil jurusan Linguistik. Hubungan 'dua sahabat tersebut terjalin tahun 1958-1964, walau setelahnya mereka berpisah karena khatam menyelesaikan studi masing-masing. Namun ditahun ;1980, merkeka bertemu kembali di Irlandia 'Dublin. Dimulailah dialog 'inteaktif membahas masalah ilmu 'bahasa, filsafat, dan Al-Qur'an;. Shahrour mencoba lebih mendalami ;bahasa, filsafat, dan Al-Qur'an . Berawal darinya, Shahrour mempelajari 'linguistik yang diperoleh riset disertasi 'Ja'far Dakk al- Bab yang dipublikasikan' di Moskow thun 1973.7

Kegigihannya sat 'mendalami AlQur'an dan filsafat bahasa, Shahrour melahirkan karya ilmia kontrovrsial, ialah

7 Muhammad Shahrour, Al- Kitab wa AlQur'an; Qira'ah al-'Mu'ashirah, (Damaskus;'Ahali li anNasyr wa at-Tawzi, 1992), 47
'Al-Kitab wa Al-Qur'an; -Qira'ah 'al-Mu'ashirah (1990)*. Buku itu adalah kumpulan hasil evolusi buah-pemikiran Shahrour selaama 20 tahun. Akan tetapi, pemikiran kontroversil Shahrour tidak trlepas dari pengaruh tokoh 'bahasa, misal Ibnu Faris, Yahya ibn 'Tsa'lab, Abu Ali al- Farisi dan 'Ibnu Jinni,.

Bisri Efendi mengutip pernyataan Eikelman-Piscatori dalam buku Al-Kitab wa Al-Qur'an; Qira'ah al-Mu'ashirab yang mencoba melantarkan kritik tajam pada kebijakan agama konvensonal dan kepastian 'radikal yang nontoleran. Harapan Shahrour adalah adnyaperlunya merepitisi' ayat AlQuran yangsesuai perkembangan dinamikai peradaban-generasi dalam memberantas 'keawaman' pemaknaan Al-Qur'an. ${ }^{8}$

\section{Pendekatan Teori Hudud (Batas) Muhammad Shahrour}

Teori batas (nazhariyyah al budund, limit theory) adalah sumbangsi besar Shahrour dalam menafsirkan ulang ayat-ayat mubkamaat (ayat-ayat hukum) dalam AlQur'an.'Teori tersebut dikonstruksikan pada dasar ajaran Islam / risalah Nabi Muhammad ialah ajaran universal ('aalamiyab) dan berkembangdan berkaitan sampai akhir 'zaman.

8 Bisri Efendi, "Tak Membela Tuhan Yang Membela Tuhan", dalam Abdurrahman Wahid, Tuban Tidak Perlu Dibela', (Yogyakarta; LkiS, 1999), hlm. Xviii . 


\section{Evi Muzaiyidah Bukhori}

Menurut Shahrour, kelebihan ajaran Islam adalah karena mengandung 2 model' gerakan, yaitu konstan (istiqaamab) dan dinamis (baniifiyyab). Inilah penyebaab Islam bersifat adaptif. Sifat tersebut tetap dalam kawasan' buduudullah (batasan hukum Allah). para rasul ;sebelumnya menerima risalah bersifat 'ainiyyah-haddiyab', berrti konkretoperasional. Sedangkan risalah RasulullahSaw bersifat budundiyyah sehingga berpotensi kesempatan ber- ijtihad dalam menyelesaikanperkara. ${ }^{9}$

Terdapat perbedaan signifikan 'baddiyyah dan budundiyyah. Hukum baddiyyah bersifat statis, fixed, dan tanpa alternatif, kemudian buduudiyyah bersifat dinamis dan dimungkinkan adanya alternatif lain dalam interpretasi”. Kamus Hans Wehr, budundiyyah diatikan: sebagai "the bounds or restrictions that God has placed on mans freedom of action (lingkaran atau batas-batas di mana Allah menempatkan kebebasan manusia untuk bertindak)". ${ }^{10}$

'Huduud dalam pandangan Shahrour bukan hanya relevan' dengan kebebasan bertindak, sesuai batas ang 'ditetapkan' Allah. Inila dasar pemikir yang kontra terhadap Shahrour enuturkan bahwa ia telah dipengruhi pemikiran 'mu'tarilah.

Rumusn 'teori budund lahir pada pemahaman serios pada dua watak risalah* Islam," yakn istiqaamah (konstan) dan

${ }^{9}$ Shahrour, Al-Kitab wa Al-Qur'an.., 40.

${ }^{10}$ Hans Wehr, A Dictionary of Modern Written Arabic,. J. Milton Cowan, cet. III, (Beirut: Librairie Duliban, 1999), 159. baniifiyyah (dinamis). Watak ini adalah oposisi latarbelakang lahirnyy "gerakan dialektik" (albarakah al-jadaliyyah), yang kemudian pembaruan pembuatan 'tasyri', baik; secara kuantitas maupun kualitas. Sehingga 'hukum 'Islam konsisten menglami pekembangan seiring problem manusia.$^{11}$

Menurut Shahrour, aspek istiqaamah adalah buduudullab (batasa- hukum Allah) kedinamisan (baniifiyyab) yang direpesentasikan kembangnya zaman dan tempat tetap berada pada batasan- hukum Allah. Relasi istiqaamah \& haniifiyyah 'memiliki peran terhadp kembangynya 'hukum Islam'. Demikian;ah hukm Islam diadaptasiikan pada perkembangan zaman. Ini mengandung arti bahwa insan' beramal dan beraktifitas pada lngkup hanïfiyyah, tetap pada batasan istiqaamah. Dikaitkan dengan konteks hukum Islam maka hanïfiyyah berari gerak dinamis yang dibangun atas dasar hukum- yang ada dalamm Al-Qur'an.

Shahrour men-klfikasi huduud pada 2 bagiaan. Pertama, al-buduud fi- 'al-ibaadah, ialah batasan' yang

'reevan 'terhadap ritual ibadah yang bersih dari medan ijtihad. Segala sesuatu bersifat 'asy-sya'aa'ir diterima begitusaja dan pemahaman-nya 'tidak berubah ssampai akhir zaman'. seperti shalat, puasa,dan haji. Konsep dan pelaksanaan "Ijtihad" pada konteks ini justru dianggap sebagai bid'ah. ${ }^{12}$ Kedua, 'al-budund fi-al-abkeam (batasan -

\footnotetext{
${ }^{11}$ Shahrour, Al-Kitab wa Al-Qur'an.., 447.

12 Shahrour, Al-Kitab wa Al-Qur'an.., 453
} 
hukum). Shahrour membagi mnjadi 6 jenis, yaitu implementasi dari 'teori hudund memakai model analisis matematis. Secara geneologis, pada awalnya teori ini dikembangkan oleh ilmuwan yang bernama Sir Issac Newton, khususnya mengenai persamaan fungsi yang dirumuskan dengan $\mathrm{Y}=\mathrm{F}(\mathrm{X})$, digunakan jika memiliki satu variabel dan $\mathrm{Y}+\mathrm{F}(\mathrm{X}, \mathrm{Z})$, digunakan jika memiliki dua variabel atau lebih.

Memahami persamaan fungsi ini menjadi keniscayaan bagi seseorang yang akan memahami ajaran Islam yang memiliki dua sisi yang berlawanan, namun saling berkaitan. Dua sisi itu adalah sisi al-istiqaamah yang bergerak konstan dan sisi al-haniifizyah yang bergerak dinamis. Hubungan antara sisi al-istiqaamah dan sisi al-haniifiyah dapat digambarkan seperti kurva dan garis lurus yang bergerak pada sebuah matriks.

Dalam kaitan dengan metode ijtihad maka wilayah ijtihad sesungguhnya berada pada kurva tersebut, di mana sumbu $\mathrm{X}$ menggambarkan konteks-waktu \& sejarah;. Sumbu Y menjelaskan UU yang di-tetapkan Allah. Dinamika ijtihad berada dlam wilayah kurva (baniifiyyah), yng bergerak sejalan dengan sumbu X. Hanya saja gerak dinamis itu dibatasi oleh budundullah, yakni sumbu Y (kurva istiqaamah) .

Aplikasi dari persamaan fungsi itu memiliki alternatif jawaban bervariasi, namun dapat disimpulkan menjadi enam macam, diantaranya tiga bentuk persamaan kuadrat, dua bentuk fungsi trigonometri, dan satu bentuk fungsi rasional. Shahrour mengimplementasikan 6 prnsip batasan' tersebut dengan dibentuk oleh hasil (range) yang merupakan gabungan 'antara -kurva terbuka dan kurva tertutup pada sumbu X dan sumbu $\mathrm{Y},{ }^{13}$;

1. Halaat hadd' 'al-a'laa, yaitu posisi batas maksimal. Ia merupakan daerah hasil (range) dari persamaan fungsi $\mathrm{Y}=\mathrm{F}(\mathrm{x})$ yang berbentu garis lengkung menghadap ke bawah (kurva tertutup), yang hanya memiliki satu titik balik maksimum, berhimpit dengan garis lurus dan sejajar dengan sumbu X .

Halaat 'badd 'al-a'laa 'mempunyai batasan maksimal sehingga penetapan hukum tidak boleh melebihi batas tersebut, tetapi boleh dibawahnya atau' berada di garis maksimal yang 'ditetapkan Allah. Misal 'ketentuan Tuhan dalam ayat- yang menjelaskan terkait hukuman setimpal' (qishaash). Misalnya tentang hukuman potong tangan bagi pencuri laki-laki maupun perempuan sebagaimana firman Allah dalam QS. alMa’idah: 38 yaitu :

"Laki-laki yang mencuri dan perempuan yang mencuri, potonglah tangan keduanya

${ }^{13}$ Shahrour, Al-Kitab wa Al-Qur'an., 579 


\section{Evi Muzaiyidah Bukhori}

(sebagai) pembalasan bagi apa yang mereka kerjakan dan sebagai siksaan dari Allah. Dan Allab Maha Perkasa' lagi Maba Bijaksana.

Menurut Shahrour, hukuman qishaash atau potong tangan merupakan batas hukuman maksimal. Dengan demikian, seorang hakim tidak boleh menetapkan hukuman kepada pencuri melebihi batas maksimal yang ditentukan Allah. Namun boleh menetapkan "hukuman yang lebih rendah" dari hukuman qishaash atau hukuman potong tangan sesuai dengan situasi dan kondisi tertentu secara adil.

2. Haalah hadd al-adnaa, yakni posisi batas minimal. Persamaan fungsi dalam posisi ini mempunyai daerah hasil berbentu kurva terbuka (parabola) yang memiliki satu titik balik minimun, terletak berhimpit dengan garis sejajar sumbu X.

Dalam keadaan ini, suatu keputusan hukum boleh dilakukan tepat pada batas minimal yang ditentukan atau di atas batas minimal yang telah ditentukan dengan syarat tidak melewti batasan' minimal tersebut. Seperti contoh ayat-ayat yang membahas tentang mahaarim (perempuan-perempuan yang tidak boleh dinikahi), sebagaimana terdapat dalam firman Allah Swt.:

Dan janganlah kamu menikabi perempuanperempuan yang telab dinikabi oleh ayabmu, terkecuali pada masa yang telah lampau (jahiliyab). Sesunggubnya perbuatan itu amat keji dan dibenci oleh Allah dan seburuk-buruknya jalan (yang ditempub). Diharamkan atas kamu (mengawini) ibu- ibumu; anak-anakmu yang perempuan; saudara-saudaramu yang perempuan; saudara-saudara bapakmu yang perempuan; saudara-saudara ibumu yang perempuan; anak-anake perempuan dari saudarasaudaramu yang laki-laki; anak-anak perempuan dari saudara-saudaramu yang perempuan; ibu-ibumu yang menyusui kamu; saudara perempuan sepersusuan; ibu-ibu istrimu (mertua); anak-anak istrimu yang dalam pemeliharaanmu dari istri yang telah kamu campuri, tetapi jïka kamu belum bercampur dengan istrimu itu (dan sudah kamu ceraikan) maka tidak berdosa kamu menikabinya; (dan dibaramkan bagimu) istri-istri anak kandungmu (menantu); dan menghimpunkan (dalam perkawinan) dua perempuan yang bersaudara, kecuali yang telah terjadi pada masa lampau (jahiliyah); sesunggubnya Allah Maha Pengampun lagi Maha Penyayang. (QS. an-Nisa': 22-23)

Ayat di atas menjelasan perempuan yang "dilarang untuk dinikahi." Akan tetapi, karena yang disebutkan adalah batas minimal maka kemngkinan besar perempuan dilarang dinikahi melebihi klaifikasi sebagaimana ayat tersebut. Seperti contoh menikahi saudara sepupu. Hukumnya boleh dilarang dengan syarat ditemukannya suatu penelitian bahwa pernikahan yang seperti itu dapat mengakibatkan keturunan yang cacat mental atau cacat fisik

3. Haalah hadd al'alaa wa al'adnaa ma'an, yaitu posisi batas maksimal dan minimal ada secara bersamaan, di mana daerah hasilnya berupa kurva gelombang yang memiliki sebuah titik balik maksimum dan minimum. Kedua titik balik tersebut 
terletak berhimpit pada garis lurus yang sejajar dengan sumbu X.

Sebagian ayat-ayat hukum mempunyai batas maksimal dan batas minimal sehingga penetapan hukum dapat dilakukan di antara kedua batas tersebut. Di antara ayat hukum yang masuk dalam kategori ini adalah ayat tentang pembagian harta waris (QS. anNisa':11 -14) dan ayat terkait poligami (QS. 'an-Nisa': 3). Pembahasan akan diuraikan lebih detail pada pembahasan tentang konsep poligami menurut Muhammad Shahrour.

4. Haalah al-Mustaqiim (posisi lurus). Daerah hasil pada posisi keempat ini berupa garis lurus yang sejajar dngan sumbu $\mathrm{X}$. Pada grafik ini, nilai $Y=f(X)$ adalah konstan untuk semua nilai X. Artnya nilai Y yang lain adalah sama karena nilai maksimal dan nilai minimal tidak ada karena nilai minimal. Jadi terdapa rumus persamaan $\mathrm{Y}=\mathrm{N} 1$ berbentuk grafik garis lurus datar

Ayat budund pada siituasi ini tidak 'mempunyai "batasan minimal" maupun maksimal sehngga tidak ada altrnatif range dari aktualisasi hukumnya terkecuali demikian disebutkan ayat. Dengan sebab ini', hukm tidak-pernah berubah walaupun terjadinya pergantian waktu. Seperi contoh, ayat tentang hukuman bagi pelaku zina. Berdasarkan ketentuan ini maka pelaku zina laki-laki bujang (mubshan) dan perempuan perawan (mubshanah) dengan dicambuk seratus kali, sebagaimana firman Allah (QS.an-Nur: 2)

"Perempuan yang berzina dan laki-laki yang beritina, maka deralah tiap-tiap seorang dari keduannya seratus kali dera, dan janganlah belas kasiban kepada keduannya mencegah kamu untuk (menjalankan) agama Allah, jika kamu beriman kepada Allah, dan hari akbirat, dan bendaklab (pelaksanaan) bukuman mereka disaksikan oleb sekumpulan dari orang-orang yang beriman."

Menurut Shahrour, dalam perbuatan 'zina harus menetapkan 'hkuman cambuk sebagaimna ayat di atas. Redaksi ayat yang menegaskan dalam ayat tersebut yaitu pada lafadz, walaa 'ta'khudzkum bibimaa ra'fatun fi diinillah "(dan janganlah belas kasihan kepada keduanya mencegah kamu untuk (menjalankan) agama Allah)".

5. Haalah 'al-hadd-al-a'laa dunna 'al-mamas bi 'al-hadd al'adnaa abadan, yakni posisi batas maksimal tanpa menyentuh garis batas minimal. Pada posisi ini, daerah hasil berupa kurva terbuka dengan titik akhir yang mendekati sumbu $\mathrm{Y}$ dan bertemu pada daerah yang tidak terhngga. Sedangkan titik pangkalnya yang terletak 


\section{Evi Muzaiyidah Bukhori}

di daerah tidak terhingga akan berhimpit dengan sumbu X.

Posisi batas maksimal ini mendekat, namun tanpa "persentuhan" ter-kecuali atas daerah yang tidak terhingga. Jika dierapkan pada ayat buduud, contonya, 'hubungan laki-laki dan perempuan yng dimulai dari hbungan non fisik, kemudian meningkat perlahan sampai ke hubungan fisik yang dsebut perzinaan.

Garis ini hanya ditandai satu titik garis lurus. Garis itu ditentukan Allah sebagai perbuatan zina, yaitu hubungan seksual antara laki-laki dan perempuan di luar nikah. Oleh karena itu, Al-Qur'an menggunakan redaksi walaa taqrabun azzinaa. Ini memberikan makna bahwa mendekati zina secara terus menerus akan menjerumuskan seseorang ke dalam perbuatan zina yang dilarang.

6. Haalah hadd al-a'laa muijab mughlaq laa yajun tajaawnzubu wa al-hadd al-adnaa saalib уајииг, tajaawгuhu ( posisi batas minimal bersifat negatif dan boleh dilampaui dan batas maksimal bersifat positif dan tidak boleh dilampau ). Hasilnya aialah kurv gelombang 'titik balik' minimum yang ada di wilayah negatif dengan titik balik maksimum yang ada di 'wlayah positif menempel dngan garis lurus sejajar dengan "sumbu X.

Implementasi hukum ini dapat dijangkau pada zakat sebagai batasan minimal negatif yng mubah dilampaui \& riba sebagai batasan maksimal positif yang haram dilanggar. Ini memiliki makna bahwa batas minimal zakat boleh untuk dilampaui di aas 2,5\%, sedangkan riba berlipat ganda tidak boleh dilanggar. Kelebihan zakat ini disebut shadaqah yng mempunyai 2 batasan; yakni maksimal yang ada pada kawasan positif dan minimal yang berada di kawasan negatif.

\section{Metode Penafsiran Poligami Menurut Quraish Shihab}

Secara bahasa poligami merupakan ikatan pernikahan salah satu pihak baik lakilaki maupun perempuan menikahi beberapa lawan jenis diwaktu yang sama. ${ }^{14}$ pemaknaan diatas mempunyai siat umum, yakni bisa digunakan untuk laki-laki yang punya istri lebih dari satu ataupun perempuan yang mempunyai suami lebih dari satu, keduanya dilaksanakan dalam waktu yang bersamaan. Tentunya hal ini berlandaskan Al-Qur'an dan Hadist Rasulullah SAW. Hal ini dapat dilihat dalam Al-Qur'an surat An-Nisa' ayat : 3 yang bermakna :

Dan jika kamu takut tidak akan dapat berlaku adil terbadap (bak-hak) perempuan yang yatim (bilamana kamu menikabinya), maka nikabilah wanitawanita (lain) yang kamu senangi: dua, tiga atau empat. Kemudian jika kamu takut tidak akan dapat berlaku adil, maka (nikabilab) seorang saja atau budak-budak yang kamu miliki. Yang demikian itu adalab lebih dekat kepada tidake berbuat aniaya.

14 M. Quraish Shihab, Wawasan Al-Qur'an: Tafsir Tematik atas Pelbagai Persoalan Umat (Bandung: Mizan, 2007), 199 
Dalam Al-qur'an tidak mewajibkan dan tidak menganjurkan seseorang untuk berpoligami, ayat tersebut menjelaskan tentang bolehnya melakukan poligami dengan adanya syarat yang tidak ringan dan hanya dapat dilakukan oleh seseorang yang sangat amat membutuhan hal tersebut. Ada beberapa hal yang harus diperhatikan menurut Quraish Shihab terkait poligami yakni 1) Peperangan yang mayoritas dilakukan oleh laki-laki dari pada perempuan serta banyaknya korban yang gugur dalam peperangan di beberapa tahu lalu, sehingga perempuan Jerman Barat menginstruksikan bahwa poligami di-benarkan meski dilakukan sementara waktu, dikarenakan pemerintah dan gereja, tidak mengizinkan adanya poligami, inilah problematika yang harus diselesaikan. 2) Terdapat penyakit kemandulan). ${ }^{15}$ Seperti yang di kutip beliau dalam bukunya yakni: ${ }^{16}$

Bukankah kemungkinan mandulnya istri, atau terjangkit penyakit parah, merupakan satu kemungkinan yang tidak aneh? Apakah jalan keluar bagi seorang suami yang dapat diusulkan untuk menghadapi kemungkinan ini? Bagaimana ia menyalur-kan kebutuban biologis atau memperoleh dambaannya untuke memiliki anak? Poligami ketika itu adalah jalan yang paling ideal. Namun harus diingat kembali peribal ini bukan berarti kebolehan,

15 M. Quraish Shihab, Tafsir Al-Misbab: Pesan, Kesan, dan Keserasian Alquran, (Tangerang: PT. Lentera Hati. 2017), 411

${ }^{16}$ Shihab, Wawasan Al-Qur'an, 200 apalagi keharusan. Itu diserahkan kepada pibak tertentu menurut pertimbangannya. AlQuran sekedar memberi ruang untuk golongan yang menginginkannya. Ada banyak keadaan selain yang disebut ini, yang juga adalab alasan masuk akal untuk tidak menutup pintu poligami dengan syarat-syarat yang tidak ringan.

Kalangan yang pro dengan adanya poligami selalu menggunakan dalil yang termaktub dalam Q.S An-Nisa': 3, akan tetapi Quraish Shihab memahami ayat tersebut dengan pandangan yang berbeda, dalam bukunya yang berjudul Tafsir AlMisbah: Pesan, kesan, dan Keserasian AlQur'an dijelaskan

Kandungan ayat tersebut babwa Allah melarang memanfaatkan barta anak yatim secara aniaya. Setelah itu, Allah melarang berlaku aniaya terbadap pribadi anak-anak yatim itu. Daripada itu, diperjelas babwa dan jika kamu khawatir tidak akan dapat berbuat adil pada perempuan yatim, dan kamu percaya diri akan berlaku adil terbadap wanita-wanita selain yatim itu, maka nikabilah apa yang kamu senangi sesuai selera kamu dan halal dari wanita-wanita yang lain itu, kalau perlu, kamu dapat menggabung dalam saat yang sama dua, tiga atau empat tetapi jangan lebih, lalu jikea kamu takut tidak dapat berlaku adil dalam hal harta dan perlakuan labiriah, bukan dalam hal cinta bila mengbimpun lebih dari seorang istri, maka nikabilab seorang saja, atau nikabi hamba sahaya wanita yang kamu miliki. Yang demikian itu, yakni menikabi selain anak yatim mengakibatkan ketidakadilan, dan mencukupkan satu orang istri adalah lebih 


\section{Evi Muzaiyidah Bukhori}

dekat kepada tidak berbuat aniaya, yakni lebib mengantarkan kamu kepada keadilan, atau kepada tidak memiliki banyak anak. yang harus kamu tanggung biaya bidup merek.a. ${ }^{17}$

Adil dalam poligami menurut Quraish Shihab berdasarkan pada Q.S An-Nisa' ayat 129 adalah adil dalam bidang immaterial (cinta), karena cinta dengan kecenderungan yang berbeda akan menyakitkan, oleh sebab itu seorang laki-laki yang berpoligami dituntut untuk mengendalikan hawa nafsu dan sikap kecenderungan kepada yang dicintai. Maka Quraish Shihab juga berpendapat bahwa keadilan dalam berpoligami menjadi syarat utama yang harus dipenuhi sebelum seseorang melakukan poligami.

\section{Penerapan Metodologi Penafsiran}

\section{Shahrour terhadap Kasus Poligami}

Shahrour memiliki pandangan menarik terkait dengan kasus poligami. Menurutnya, sebab ayat poligami yaitu QS. an-Nisa': 3 diletakkan di awal surat karena poligami adalah satu diantara tema yang mendapat perhatian khusus dari Allah. Namun menurut Shahrour, para mufassir dan ahli fiqh melalaikan redaksi umum ayat tersebut dan keterkaitan erat antara poligami dengan penyantunan terhadap para janda dan anakanak yatim. ${ }^{18}$ Meski pada kenyataannya terdapat keterkaitan antara penyantunan anak-anak yatim dan para janda. Dalam

17 M. Quraish Shihab, Tafsir Al-Misbah: Pesan, Kesan, dan Keserasian Alquran, 366

${ }^{18}$ Muhammad Shahrour, Metodologi Fiqih.., 427 rangka membuktikan pernyataan tersebut Shahrour melakukan penafsiran terhadap ayat poligami melalui metode tartiil dengan menggunakan analisis paradigmatik sintagmatis, sebagai berikut:

Pada Surat an-Nisa' ayat pertama, Allah mengajak manusia untuk bertakwa kepada-Nya, menyambung tali silaturahmi antara sesama tanpa dibatasi oleh sekat-sekat hubungan keluarga atau kesukuan yang sempit. Sebagaimana dalam firman Allah Swt:

Hai sekalian manusia, bertakwalah kepada Tuban-mu yang telah menciptakan kamu dari diri yang satu, dan daripadanya Allah menciptakan istrinya; dan daripadanya keduanya Allah memperkembangbiakean lakilaki dan perempuan yang banyak. Dan bertakwalah kepada Allah yang dengan (mempergunakan) nama-Nya kamu saling meminta satu sama lain, dan (peliharalab) bubungan silaturrabim. Sesunggubnya Allah selalu menjaga dan mengawasi kamu. (QS. anNisa': 1)

Kemudian ayat keduanya membahas penyatunan anak yatim dan perintahlarangan memakan harta mereka'.

'Dan berikanlah kepada anak-anak yatim (yang sudah baligh) harta mereka, jangan kamu menukar yang baik dengan yang buruk, dan jangan kamu makan harta mereka bersama bartamu." Sesunguhnya tindakan-tindakan (menukar dan memakan) itu, adalah dosa yang besar'. (QS. an-'Nisa': 2)

Sesudah Allah Swt memerintahkan hamba-Nya agar bertakwa kepada-Nya, menyambung tali silaturahmi, dan memperdulikan -anak yatim dan para janda, 
kemudian Allah berfirman dalam Alquran tentang poligami,

Dan jika kamu takut tidak akan dapat berlaku adil terhadap (bak-bak) perempuan yatim (bilamana kamu mengawininya), maka kawinilah perempuan-perempuan lain (yang dimaksud menurut Shabrour adalah para janda) yang kamu senangi: dua, tiga, atau empat. Kemudian jika kamu takut tidak akan dapat berlaku adil, maka (kawinilah) seorang saja, atau budak-budak yang kamu miliki. Yang demikian itu akan lebih bisa menjaubkan kamu dari berbuat aniaya (QS. an-Nisa': 3)

Kecermatan Shahrour dalam mengkaji ayat poligami menunjukkan bahwa ia benarbenar mempertimbangkan aspek struktur kalimat, hubungan linier (sintagamatis) antara kata dalam satu ayat, hubungan paradigmatik serta pengaruh strukturalisme linguistik. Ia juga konsisten dengan prinsip-prinsip hermeneutika takwilnya, di mana seorang mufasir dalam memahami ayat harus menggunakan pendekatan tartil, yaitu mengumpulkan ayat-ayat setema untuk mendapatkan pandangan yang komprehensif sehingga tidak terjebak pada pemahaman yang parsial. Dengan pendekatan tartil, Shahrour mencapai benang merah bahwa poligami dibolehkan dengan syarat berada pada kondisi darurat dan Islam menganut prinsip monogami.
Dengan teori buduud-nya, ${ }^{19}$ Shahrour membuat dua persyaratan bagi orang-orang yang akan melakukan poligami. Pertama, syarat kammiyyah (kuantitas), yakni batasan mengenai jumlah perempuan yang dipoligami. Menurutnya, batas minimal poligami adalah dua sementara batas maksimalnya adalah empat. Kedua, syarat naw'iyyah (kualitas), yakni menyangkut kualitas orang yang hendak melakukan poligami; bahwa orang yang akan melakukan poligami harus ada kekhawatiran dalam dirinya tidak dapat berbuat adil kepada anakanak yatim, namun dia harus berusaha untuk dapat berlaku adil, dan bahwa perempuan yang hendak dipoligami harus berstatus janda serta memiliki anak yatim. ${ }^{20}$ Jika syaratsyarat tersebut tidak dipenuhi maka seseorang tidak perlu melakukan poligami dan cukup menikah dengan satu istri saja, seperti dinyatakan Allah dalam Alquran surah. 'an-Nisa'; 3.

Poin menarik dari pemikiran Shahrour mengenai poligami ini adalah ia memandang bahwa poligami bukan hanya diperbolehkan, bahkan dianjurkan terhadap yang bisa melengkapi dua syarat tersebut kuantitas dan

19 Teori buduud digunakan oleh Shahrour untuk memahami Al-Quran sebab ayat poligami relevan dengan masalah hukum. Penulis jelaskan pada metodologi penafsiran Shahrour, bahwa-ayatayat mubkamat. Shahrour memakai model ijtihad dengan teori- budund.

${ }^{20}$ Shahrour, Metodologi Fiqih.., 431 


\section{Evi Muzaiyidah Bukhori}

syarat kualitas). Menurutnya membantu nasib para janda dan anak-anak yatim. Adalah missi yang sangat baik dari dibolehkannya ber-poligami.

Pada tahun 1991 terdapat pembatasan poligami yang diatur dalam INPRES No. 1 tentang pemberlakukan Kompilasi Hukum Islam (KHI) dalam pasal 55 ayat (1) yang berbunyi; "Beristri lebib dari satu orang pada waktu bersamaan, terbatas hanya sampai empat orang istri". Dapat disimpulkan bahwa poligami dalam Undang-undang Perkawinan (UUP) dan KHI, tentang syarat seorang lakilaki yang ingin berpoligami dengan mendapatkan izin dari pengadilan, dan syarat itu terdapat pada istri pertama/sebelumnya seperti istri tidak dapat menjalankan kewajibannya, mengidap penyakit yang tidak dapat disembuhkan serta tidak bisa melahirkan keturunan (mandul). Kemudian konsep Adil diatur dalam undang-undang pernikahan ayat 5 tentang "adanya persetujuan istri petama/sebelumnya" dikarenakan maraknya poligami yang dilakukan secara diam-diam sehingga menimbulkan perbuatan dhalim terhadap perempuan dan tentunya bertentangan dengan Q.S An-Nisa' ayat 3. Selain itu pada pasal 5 UUP dan 41 ayat 3 KHI tentang jaminan finansial untuk kebutuhan hidup istri-istri beserta anakanaknya, serta memberlakukan secara adil terhadap istri-istri dan anak - anaknya. Ulama Syafi'iyah mengatakan dalam kitab alUmm yang berkaitan dengan urusan fisik berupa perkataan dan perbuatan, bukan masalah hati. Q.S An-Nisa' ayat 129 menjelaskan bahwa hati manusia selamanya tidak bisa berlaku adil. ${ }^{21}$

Berbeda dengan konsep adil menurut pandangan Muhammad Syahrour yang dijadikan syarat utama dalam poligami ini terkait dengan adil kepada anak-anaknya sendiri (istri pertama) dengan anak yatim (anak janda/istri selanjutnya) bukan terkait dengan istri-istri mereka.

\section{Simpulan}

Berdasarkan uraian di atas, maka penulis dapat menyimpulkan beberapa kesimpulan, di antaranya sebagai berikut:

Pembacaan Shahrour terhadap AlQur'an dipengaruhi oleh setting sosial di mana ia hidup. Terutama pergumulannya dengan teman sekaligus guru yang bernama Ja'far Dakk al-Bab. Shahrour mengawali mengkaji Al-Qur'an secara lebih serius dengan pendekatan teori linguistik, filsafat, dan sains modern. Shahrour bahkan kemudian menulis beberapa buku dan artikel tentang pemikiran keislaman. Pertemuan Shahrour dengan Ja'far Dakk al-Bab terjadi ketika keduanya menjadi mahasiswa di Uni Soviet. Pada saat itu, Ja'far mengambil jurusan Linguistik, sedangkan Shahrour mengambil Jurusan Teknik Sipil. Persahabatan itu terjadi sekitar tahun 1958 hingga 1964, meskipun setelah itu

21 Miftahul Huda, Hukum Keluarga, (Malang: Setara Press, 2018), 95 
keduannya berpisah karena sama-sama telah selesai dalam studinya.

Muhammad Shahrour memandang salah satu problem terbesar dalam penafsiran Al-Qur'an adalah problem aplikasi metodologi penafsiran. Hal ini berarti membahas tentang konsep-konsep teoritis mengenai proses dan prosedur yang dipakai oleh para mufasirin dalam melakukan penafsiran. Ia juga bagian dari epistemologi yang mengakaji tentang langkah-langkah yang harus ditempuh agar pengetahuan yang diperoleh memenuhi kaidah ilmiah. Selain itu, metodologi juga dipandang sebagai sebagai bagian dari logika yang mengkaji tentang asumsi yang melatarbelakangi munculnya sebuah metode. Dalam persoalan ini, Shahrour menggunakan beberapa prinsip dalam penafsiran terhadap Al-Qur'an sebagaimana yang telah dikemukakan di atas.

Konsep kunci pemikiaran Shahrour adalah teori tentang Hudud. Teori ini terutama dipakai untuk membaca persoalanpersoalan hukum yang terdapat dalam ajaran Islam. Dalam teori ini, Shahrour menggunakannya untuk membedah persoalan-persoalan perempuan, terutama masalah poligami yang ramai dibicarakan oleh kebanyakan masyarakat. Dalam menganalisis tentang poligami, Shahrour memiliki pemahaman yang unik dibandingkan dengan ulama-ulama terdahulu. Pada penafsiran ini juga, Shahrour dikenal sebagai pemikir Islam kontemporer yang kontroversial.

\section{Daftar Pustaka}

Abduh, Muhammad. Tafsir Jur 'Amma. Mesir: Al-Jam'iyyah al-Khairiyyah, $1341 \mathrm{H}$.

Asy-Shaydawi, Yusuf. 'Baydhah ad-Diik; Naqd al-Lughawii -li Kitaab 'Al-Kitaab wa Al-Quraan. Mathba'ah atTa'awuniyyah, tt.

Baljon, J.M.S. The Reform and Religious Ideas of Sir Sayyid Ahmad Khan. Leiden: Ej-Brill, 1949.

Farouki, Taji. Modern Muslim Intellectuals and the Qur'an. New York: Oxford University Press, 2004.

Huda, Miftahul. Hukum Keluarga. Malang: Setara Press, 2018.

Kurzman, Charles, (ed.). Liberal Islam. New York: Oxford University Press, 1998.

Mustaqim, Abdul. Epistemologi Tafsir Kontemporer. Yogyakarta: LkiS, 2011.

Shihab, M. Quraish. Wawasan Al-Qur'an: Tafsir Tematik atas Pelbagai Persoalan Umat. Bandung: Mizan, 2007.

Tafsir Al-Misbab: Pesan, Kesan, dan Keserasian Alquran. Tangerang: PT. Lentera Hati, 2017.

Shah, M. Aunul Abied. et al. (ed.). Islam Garda Depan: Mosaik Pemikiran Islam Timur Tengah. Bandung: Mizan, 2001.

Shahrour, Muhammad. Al-Kitab wa AlQur'an; Qira'ah al-Mu'ashirah. Damaskus: Ahali li an-Nasyr wa atTawzi, 1992.

Shahrour, Muhammad. Metodologi Fiqib Islam Kontemporer, terj. Sahiron Syamsuddin. Yogyakarta: eLSAQ, 2003.

Wahid, Abdurrahman. Tuban Tidak Perlu Dibela. Yogyakarta: LkiS, 1999.

Wehr, Hans. A Dictionary of Modern Written Arabic, J.; Milton Cowan, cet. III. Beirut: Librairie Duliban, 1999. 